\title{
長周期波と港湾の周辺形状との関連について
}

\author{
久保 雅義 $*$ ・前田 保男** \\ 片山 哲三***斎藤 勝彦 *
}

\section{A Study on the Relationship between Long-Period Waves and Surrounding Land Form of Harbors}

\author{
Masayoshi KUBO, Yasuo MAEDA, \\ Tetsuzo KATAYAMA and Katsuhiko SAITO
}

\begin{abstract}
Harbors facing to open-sea are sometimes troubled with long-period waves. Long-period waves cause harbor oscillations, and damage moored ships and adjacent structures.

So far some studies on harbor oscillations have been carried out, and calculation models have been developed. Previous analytical studies can be divided into two groups. The first is the method that the basic solution of the Helmholtz equation is expressed in terms of an infinite series. The second is expressed in terms of the zero order Hankel function of the first kind alone.

Applying the second method, a new calculation model is developed in this paper. This model is applicable to harbors which have arbitary boundary in the open-sea region as well as the harbor region.

Some details about the new model are given in the 2nd chapter. In the 3 rd chapter, the numerical results are compared with previous study. Then the model is applied to three familiar harbors.

The obtained results are summarized as follows;

(1)About the integral of coastline parts, the tip of the boundary is set at the point that the radiated wave function attenuats to $1 / 10$.

(2)In spite of the difference in the surrounding land form of the harbors, each resonant period resembles, and the wave patterns in the harbor region for the resonant modes is very similar to each other.

(3)In the open-sea region, long-period waves have a different influence on the wave pattern according to the surrounding land form of the harbors.
\end{abstract}

\section{1.はじめに}

外洋に面して建設された港湾においては、当地の気象・海象が稳やかな状態であるにもかかわらず、長 周期波の影響を受ける。実際、現地観測及び数值計算により、周期 150 (秒)、波高 $30 \mathrm{~cm}$ の長周期波の場合、 $60,000 \mathrm{DWT}$ 級の船舶がSurge方向に $6 \mathrm{~m}$ 程度動くことが明らかになっており(1)、長周期波が重要視されつ つある。

浅海域における長周期波は二つの主な要因により、必然的に発生することが知られている。一つは、不

* 正 会 員 神戸商船大学（干658 神戸市東灘区深江南町5丁目1-1)

** 学生会員 神戸商船大学大学院（干658 神戸市東灘区深江南町5丁目1-1)

***非 会 員 株式会社エム・オー・マリンコンサルティング（テ108 東京都港区海岸3丁目18番1号） 
規則性をもつ沖波の連なりから生じる二次波として の長周期波 (set-down波) であり(2)、もう一つは、 研波による質量輸送が引き起こすサーフ・ビート（wave set-up）である(3)(4)。長周期波が港内に侵入すると、 長周期波周期と港内形状に応じて決まる固有振動周 期とが近ければ、共振現象によって港内波高は增幅 される。このとき係留船舶は大きく動摇し、荷役中 止や係留索切断などの事態が引き起こされ、荷役稼 働率に影響を与えることになる(5)。

港内副振動現象の数学モデルについて、水深が変 化する場合には緩勾配方程式、一様水深の場合には ヘルムホルッ方程式が基礎方程式である。へルムホルッ方程式はその 基本解が、(1)無限級数形で表現されるもの、(2)零次のハンケル関数の みで表現されるものに分類される。へルムホルッ方程式を基礎方程式

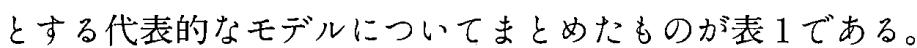

Chen, H.S. et $\mathrm{al}^{(6)}$ 、松岡(7)、坂井ら ${ }^{(8)}$ は(1)のモデルを用いて有限要 素法により、任意形状港湾における副振動現象の解析を行った。この 手法は、港外の無限領域に仮想境界の概念を導入している。また、境 界内の有限領域内には多くの計算点を設定して解を求める必要があり、 そのため計算点を設定する港外領域は狭い。

さらに、合田(9)は(1)のモデルを用いて、長方形港および扇形港にお ける副振動の解析を行った。これは、港のもつ特殊な形状の境界条件 を利用することにより未知数の数を減らし、連立方程式をたてて無限 級数における末知数を決定している。

一方、Lee ${ }^{(10)}$ は(2)のモデルを用いて、積分方程式法 (境界要素法)により解析を行った。このLeeによる 手法は、図 1 のように、港内形状については任意形状港湾に対して適用できるものの、港外形状について は「海岸線が直線状に左右遠方まで延びている」という前提条件が果されている(11)(12)。また、日下ら Leeの方法にならって、海岸線から突出した防波堤を取り囲む積分経路をとることにより、任意の港外形状 を有する港湾に適用できるモデルを提案している。しかし、このモデルを用いた場合には、最終的に帰着 する連立方程式の未知数が多く、文献(13)では実際の計算および散乱波の性質の検討はされていない。

長周期波は短周期波と比べて周期が長く、波長が大きいため、海岸線など港外の周辺形状の様子に応じ て、港内波高が影響を受けると考えられる。そこで今回、グリーン関数法を用いて、港内形状だけでなく、 港外の周辺形状をも考慮できる港内副振動の数值計算手法を開発した。本報告では、第 2 章で計算手法に ついて述べ、第 3 章でモデルの妥当性を検証するとともに、具体的な任意の港湾形状に対して数值計算手 法を適用し、その結果について考察する。

\section{2. 周辺形状を考慮した副振動の数値計算の方法}

\section{1 数值計算の数学モデル}

数値計算手法の数学モデルを次に示す。

流体場が非回転・非圧縮・非粘性であるとき、流体は速度ポテンシャルФをもち、このФはラプラス方程 式(1)で支配される。

$$
\frac{\partial^{2} \Phi}{\partial x^{2}}+\frac{\partial^{2} \Phi}{\partial y^{2}}+\frac{\partial^{2} \Phi}{\partial z^{2}}=0
$$

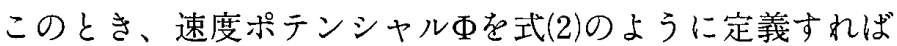

$$
\Phi(x, y, z, t)=\frac{1}{-i \sigma} \cdot f(x, y) \cdot Z(z) \cdot \exp \{-i \sigma t\}
$$


変数分離により、式(3)のヘルムホルッ方程式が得られ る。

$$
\frac{\partial^{2} f}{\partial x^{2}}+\frac{\partial^{2} f}{\partial y^{2}}+k^{2} f=0
$$

また、底面 $z=-h$ ( h中水深) $と$ 自由水面 $z=0$ における 境界条件とを考虑すると、速度ポテンシャル 式を用いることができる。

$$
\Phi(x, y, z, t)=\frac{1}{i \sigma} \cdot \frac{A g \cosh k(h+z)}{\cosh k h} \cdot f(x, y) \cdot \exp \{-i \sigma t\}
$$

ここに、tは時刻、 $\sigma$ は角周波数、Aは入射波振幅、 $g$ は 重力加速度、kは波数である。式(4)において、任意形状 港湾の流体場を考える場合、 $f(x, y)$ は水面の各場所にお ける波高分布を表わすので、以下 $f$ を波高分布関数と呼 ぶことにする。

そこで、図 2 のような任意形状港湾を考える。水面

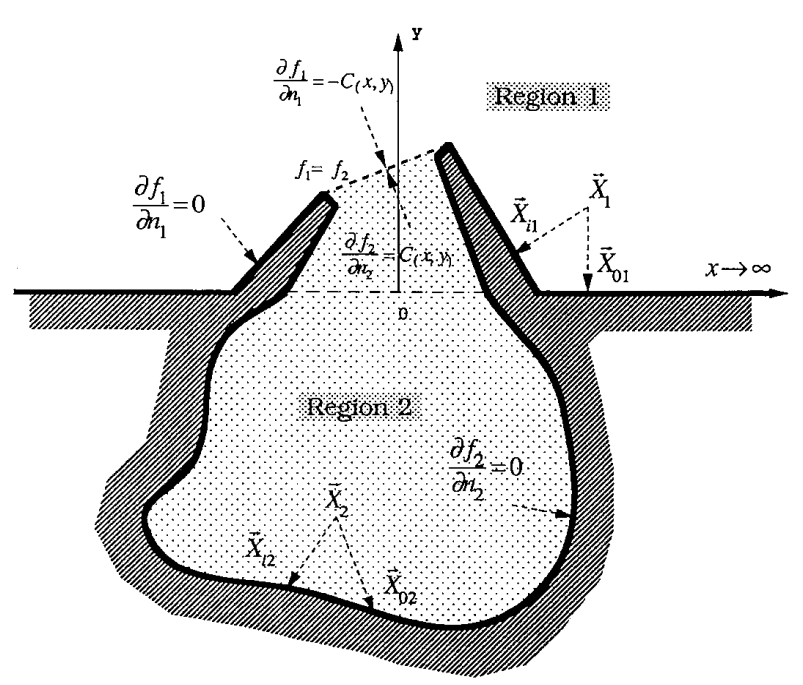

図 2 今回グリーン関数法を適用する任意形状港湾 を港外領域 1 港内領域 2 とに分割し、領域 1 に和ける波高分布関数を $f_{1}$ 、領域 2 における波高分布関数を $f_{2}$ と表わす。また、座標原点を四 2 のようにとり、x軸は海岸線に一致させる。

港外領域 1 の波高分布関数 $f_{1}$ 、港内領域 2 の波高分布関数 $f_{2}$ は式(3)のへルムホルツ方程式を満足しなけれ ばならない。ここで、グリーン関数法を用いれば、境界条件を満足する波高分布関数 $f_{2}\left(\vec{X}_{2}\right)$ は式(5)のよう に表わすことができる。

$$
f_{2}\left(\vec{X}_{2}\right)=-\frac{i}{4} \int_{\partial_{2}}\left\{f_{2}\left(\vec{X}_{02}\right) \frac{\partial}{\partial n_{2}}\left[H_{0}^{(1)}(k r)\right]-H_{0}^{(1)}(k r) \frac{\partial}{\partial n_{2}}\left[f_{2}\left(\vec{X}_{02}\right)\right]\right\} d s
$$

ここに、 $\vec{X}_{2}$ は港内領域 2 に打ける任意点、 $\partial_{2}$ は港内領域 2 の境界、 $\vec{X}_{02}$ は領域 2 の境界の位置ベクトル、 $r$ 距離 $\left|\vec{X}_{2}-\vec{X}_{02}\right| 、 n_{2}$ は港内領域 2 の内側からみた外向き法線である。また、 $H_{0}^{(1)}(k r)$ は第 1 種 0 次の八 ンケル関数である。式(5)は、港内境界上の $f_{2}$ と $\partial f_{2} / \partial n_{2}$ とを知ることができれば、港内任意点における波高 分布関数 $f_{2}\left(\vec{X}_{2}\right)$ が得られることを示している。

つぎに、港内境界上の $f_{2}$ と $\partial f_{2} / \partial n_{2}$ を求める方法を述べる。境界上の $f_{2}\left(\vec{X}_{i 2}\right)$ は、境界が滑らかなときには、 $\vec{X}_{2}$ を境界上の点 $\vec{X}_{i 2}$ に近づけることにより求められる(図 2 )。これは式(6)で表わされる。

$$
f_{2}\left(\vec{X}_{i 2}\right)=-\frac{i}{2} \int_{\partial_{2}}\left\{f_{2}\left(\vec{X}_{02}\right) \frac{\partial}{\partial n_{2}}\left[H_{0}^{(1)}(k r)\right]-H_{0}^{(1)}(k r) \frac{\partial}{\partial n_{2}}\left[f_{2}\left(\vec{X}_{02}\right)\right]\right\} d s
$$

ここに、rは距離 $\left|\vec{X}_{i 2}-\vec{X}_{02}\right|$ である。

港内境界上の $\partial f_{2} / \partial n_{2}$ を求める。 $\partial f_{2} / \partial n_{2}$ は港口部を除いて零であるから、港口部の $\partial f_{2} / \partial n_{2}$ だけを求めれ

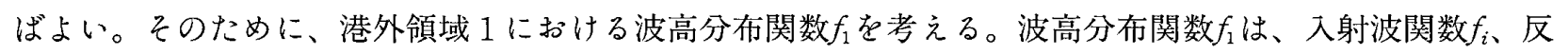
射波関数 $f_{r}$ 、散乱波関数 $f_{3}$ 用いて次式で表わされる。

$$
f_{1}(x, y)=f_{i}(x, y)+f_{r}(x, y)+f_{3}(x, y)
$$

境界条件を満足する散乱波関数 $f_{3}\left(\vec{X}_{1}\right)$ は式(5) と同様に表わすことができ、式(8)となる。

$$
f_{3}\left(\vec{X}_{1}\right)=-\frac{i}{4} \int_{\partial_{1}}\left\{f_{3}\left(\vec{X}_{01}\right) \frac{\partial}{\partial n_{1}}\left[H_{0}^{(1)}(k r)\right]-H_{0}^{(1)}(k r) \frac{\partial}{\partial n_{1}}\left[f_{3}\left(\vec{X}_{01}\right)\right]\right\} d s
$$

ここに、 $\vec{X}_{1}$ は港外領域 1 に和ける任意点、 $\partial_{1}$ は港外領域 1 の境界、 $\vec{X}_{01}$ は領域 1 の境界の位置ベクトル、 $r$ は距離 $\left|\vec{X}_{1}-\vec{X}_{01}\right| 、 n_{1}$ は港外領域 1 からみた外向き法線である。

港外任意点 $\vec{X}_{1}$ の散乱波関数 $f_{3}\left(\vec{X}_{1}\right)$ を求めるとき、積分範囲 $\partial_{1}$ 、四 3 に示すように、無限に続く左の海岸 線部分： $\partial L C L$ 、左の防波堤部分： $\partial L B W$ 、港口部分： $\partial H E$ 、右の防波堤部分： $\partial R B W$ 、無限に続了右の 海岸線部分： $\partial R C L$ 、半径を無限長と考兄る円周部分： $\partial R$ に分けられ、式(9)のように表現できる。

$$
f_{3}\left(\vec{X}_{1}\right)=-\frac{i}{4} \int_{\partial L C L+\partial L B W+\partial H E+\partial R B W+\partial R C L+\partial R}\left\{f_{3}\left(\vec{X}_{01}\right) \frac{\partial}{\partial n_{1}}\left[H_{0}^{(1)}(k r)\right]-H_{0}^{(1)}(k r) \frac{\partial}{\partial n_{1}}\left[f_{3}\left(\vec{X}_{01}\right)\right]\right\} d s
$$

式(9)において、放射条件を用いれば区間 $\partial R の$ 積分は零となる。 


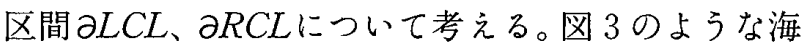
岸線が左右一直線に延びている場合には、入射波 $f_{i}$ ・反 射波 $f_{r}$ を式(10)のように与えれば、 $\partial f_{i} / \partial n_{1}+\partial f_{r} / \partial n_{1}=0$ であり、港外の完全反射境界に沶いて

$$
\partial f_{1} / \partial n_{1}=\partial f_{i} / \partial n_{1}+\partial f_{r} / \partial n_{1}+\partial f_{3} / \partial n_{1}=0
$$

であるから

$$
\begin{aligned}
\partial f_{3} / \partial n_{1} & =0 \text { となる。 } \\
f_{i} & =\exp \{-i k(x \cos \alpha+y \sin \alpha)\} \\
f_{r} & =\exp \{-i k(x \cos \alpha-y \sin \alpha)\}
\end{aligned}
$$

ここに、 $\alpha$ は入射角である。



$$
\partial f_{1} / \partial n_{1}=\partial f_{i} / \partial n_{1}+\partial f_{r} / \partial n_{1}+\partial f_{3} / \partial n_{1}=0 \text { であるか }
$$

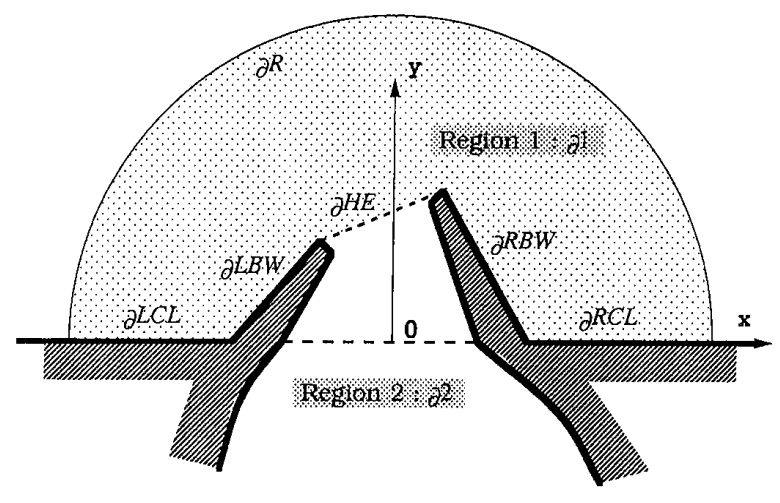

四 3 港外の積分境界 ら、 $\partial f_{3} / \partial n_{1}$ は次式により確定する。

$$
\frac{\partial f_{3}}{\partial n_{1}}=-\left(\frac{\partial f_{i}}{\partial n_{1}}+\frac{\partial f_{r}}{\partial n_{1}}\right)
$$

よって、書き換えると式(12)となる。

$$
\begin{aligned}
f_{3}\left(\vec{X}_{1}\right)=- & \frac{i}{4} \int_{\partial L C L}\left\{f_{3}\left(\vec{X}_{01}\right) \frac{\partial}{\partial n_{1}}\left[H_{0}^{(1)}(k r)\right]\right\} d s-\frac{i}{4} \int_{\partial L B W}\left\{f_{3}\left(\vec{X}_{01}\right) \frac{\partial}{\partial n_{1}}\left[H_{0}^{(1)}(k r)\right]\right. \\
& \left.+H_{0}^{(1)}(k r)\left[\frac{\partial f_{i}}{\partial n_{1}}+\frac{\partial f_{r}}{\partial n_{1}}\right]\right\} d s-\frac{i}{4} \int_{\partial H E}\left\{f_{3}\left(\vec{X}_{01}\right) \frac{\partial}{\partial n_{1}}\left[H_{0}^{(1)}(k r)\right]\right. \\
& \left.-H_{0}^{(1)}(k r) \frac{\partial}{\partial n_{1}}\left[f_{3}\left(\vec{X}_{01}\right)\right]\right\} d s-\frac{i}{4} \int_{\partial R B W}\left\{f_{3}\left(\vec{X}_{01}\right) \frac{\partial}{\partial n_{1}}\left[H_{0}^{(1)}(k r)\right]\right. \\
& \left.+H_{0}^{(1)}(k r)\left[\frac{\partial f_{i}}{\partial n_{1}}+\frac{\partial f_{r}}{\partial n_{1}}\right]\right\} d s-\frac{i}{4} \int_{\partial R C L}\left\{f_{3}\left(\vec{X}_{01}\right) \frac{\partial}{\partial n_{1}}\left[H_{0}^{(1)}(k r)\right]\right\} d s
\end{aligned}
$$

式(12)は、 $\partial R$ を除く境界上の $f_{3}$ 、港口部の $\partial f_{3} / \partial n_{1}$ が求められれば、港外任意点 $\vec{X}_{1} に$ に括る波高分布関数 $f_{3}\left(\vec{X}_{1}\right)$ が得られることを示している。また、港外境界上の $f_{3}\left(\vec{X}_{i 1}\right)$ は、式(6)を求めたときと同様にして、式(13)で表 わされる。

$$
\begin{aligned}
f_{3}\left(\vec{X}_{i 1}\right)=- & \frac{i}{2} \int_{\partial L C L}\left\{f_{3}\left(\vec{X}_{01}\right) \frac{\partial}{\partial n_{1}}\left[H_{0}^{(1)}(k r)\right]\right\} d s-\frac{i}{2} \int_{\partial L B W}\left\{f_{3}\left(\vec{X}_{01}\right) \frac{\partial}{\partial n_{1}}\left[H_{0}^{(1)}(k r)\right]\right. \\
& \left.+H_{0}^{(1)}(k r)\left[\frac{\partial f_{i}}{\partial n_{1}}+\frac{\partial f_{r}}{\partial n_{1}}\right]\right\} d s-\frac{i}{2} \int_{\partial H E}\left\{f_{3}\left(\vec{X}_{01}\right) \frac{\partial}{\partial n_{1}}\left[H_{0}^{(1)}(k r)\right]\right. \\
& \left.-H_{0}^{(1)}(k r) \frac{\partial}{\partial n_{1}}\left[f_{3}\left(\vec{X}_{01}\right)\right]\right\} d s-\frac{i}{2} \int_{\partial R B W}\left\{f_{3}\left(\vec{X}_{01}\right) \frac{\partial}{\partial n_{1}}\left[H_{0}^{(1)}(k r)\right]\right. \\
& \left.+H_{0}^{(1)}(k r)\left[\frac{\partial f_{i}}{\partial n_{1}}+\frac{\partial f_{r}}{\partial n_{1}}\right]\right\} d s-\frac{i}{2} \int_{\partial R C L}\left\{f_{3}\left(\vec{X}_{01}\right) \frac{\partial}{\partial n_{1}}\left[H_{0}^{(1)}(k r)\right]\right\} d s
\end{aligned}
$$

ここに、rは距離 $\left|\vec{X}_{i 1}-\vec{X}_{01}\right|$ である。

式(13)の海岸線部分 $\partial L C L 、 \partial R C L の$ 積分について、 海岸線が無限に続くため、この積分を行うことは 不可能である。しかし、第 1 種ハンケル関数が減 衰する特性をもつことから、仮想領域を設定し、 その範囲だけを積分することにより近似的に扱え $3^{(14)(15)}$ 。本報告では、計算機の制限と長周期波の 波長とを考慮して、水深が $5.0 \mathrm{~m}$ で一定のとき、散 乱波の減衰項 $\sqrt{1 / \pi k r} 力^{3} 1 / 10 と 1 / 24$ に減衰する距離 を海岸線の長さとする計算を次章で行った。図 4 に長周期波の周期と想定する海岸線の長さとの関 係を示す。これにより、港外境界上の点 $\vec{X}_{i 1} に お け$

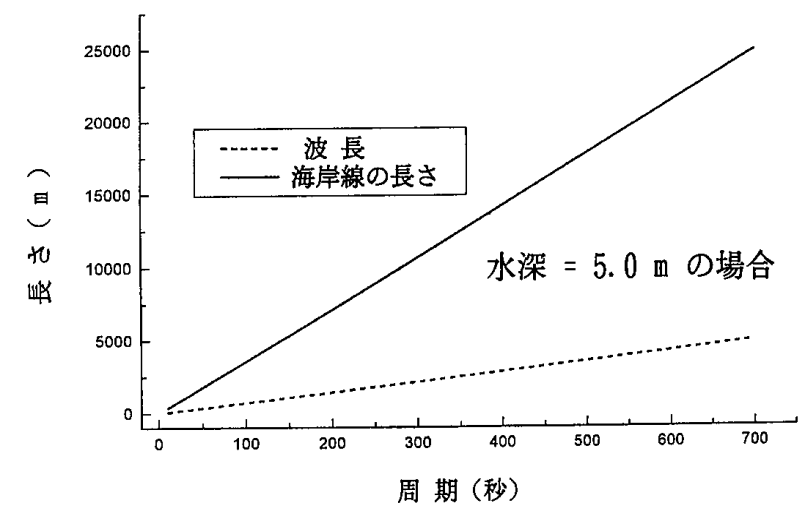

困 4 長周期波の周期と想定する海岸線の長さとの関係 
る波高分布関数 $f_{3}\left(\vec{X}_{i 1}\right)$ ガ式(13)により与えられ、式(7)から波高分布関数 $f_{1}\left(\vec{X}_{i 1}\right)$ が求为られる。

そこで、次式で表わされる接続条件を用いることにより

$$
f_{1}=f_{2}, \frac{\partial f_{2}}{\partial n_{2}}=-\frac{\partial f_{1}}{\partial n_{1}}=-\frac{\partial f_{i}}{\partial n_{1}}-\frac{\partial f_{r}}{\partial n_{1}}-\frac{\partial f_{3}}{\partial n_{1}}
$$

港口部の $\partial f_{2} / \partial n_{2} に つ い て の$ 連立方程式が導出できる。よって、港内境界上のすべての $f_{2}\left(\vec{X}_{i 2}\right)$ が定まり、式 (5)から港内任意点の $f_{2}\left(\vec{X}_{2}\right)$ が計算できる。また、港外境界上の $f_{3}\left(\vec{X}_{i 1}\right)$ も求如られ、港外任意点の $f_{1}\left(\vec{X}_{1}\right)$ が 計算できる。

以上が周辺形状を考虑した数值計算手法の数学モデルである。

\section{2 数值計算の計算モデル}

ここでは、数学モデルを離散化し、計算モデルを作成する。これにより、計算機で数值解を得ることが できる。

2.2 .1 港内境界上の波高分布関数

港内境界上の波高分布関数 $f_{2}\left(\vec{X}_{i 2}\right)$ 在求为る式(6)について、境界を十分大きな数 $N(N$ 個の微小境界要素) に分割すると、各々の境界要素において $f_{2}$ と $\partial f_{2} / \partial n_{2}$ は一定であり、その值をその要素の中央点における值 で代表させることができる。よって、離散化すると式(15)となる。

$$
(F 2)_{i}=-\frac{i}{2}\left[\sum_{j=1}^{N}\left(G 2_{n 2}\right)_{i j}(F 2)_{j}-\sum_{j=1}^{N}(G 2)_{i j}\left(F 2_{n 2}\right)_{j}\right], \quad(i=1,2, \cdots, N)
$$

ここで、式(15)中の各記号は次の通りである。

$$
\begin{aligned}
& (F 2)_{i}=f_{2}\left(\vec{X}_{i 2}\right), \quad(i=1,2, \cdots, N) \\
& \left(G 2_{n 2}\right)_{i j}=-k \cdot H_{1}^{(1)}\left(k r_{i j}\right) \frac{\partial r_{i j}}{\partial n_{2}} \Delta \partial 2_{j}, \quad(i, j=1,2, \cdots, N ; i \neq j) \\
& \left(G 2_{n 2}\right)_{i i}=2 \int_{0}^{\frac{1}{2} \Delta \partial 2_{i}}\left(-k \cdot H_{1}^{(1)}(k r) \frac{\partial r}{\partial n_{2}}\right) d s, \quad(i=1,2, \cdots, N) \\
& (G 2)_{i j}=H_{0}^{(1)}\left(k r_{i j}\right) \Delta \partial 2_{j}, \quad(i, i=1,2, \cdots, N ; i \neq j) \\
& (G 2)_{i i}=2 \int_{0}^{\frac{1}{2} \Delta \partial 2_{i}} H_{0}^{(1)}(k r) d s, \quad(i=1,2, \cdots, N) \\
& \left(F 2_{n 2}\right)_{j}=\frac{\partial}{\partial n_{2}} f_{2}\left(\vec{X}_{j}\right), \quad(j=1,2, \cdots, N)
\end{aligned}
$$

式(15)をマトリックス表示して、まとめると次式のようになる。

$$
\left.\{\mathrm{F} 2\}=\left([\mathrm{I}]+\frac{i}{2}\left[\mathrm{G} 2_{n 2}\right]\right)^{-1}\left(\frac{i}{2}[\mathrm{G} 2] \cdot[\mathrm{U} 2] \cdot[\mathrm{C} 2]\right\}\right)=[\mathrm{M} 2]\{\mathrm{C} 2\}
$$

ここに、\{＼$は列ベクトル、［］はマトリックス、[I] は単位行列を表わす。また、港口の分割数をP } P$ して、[U2]は港内の完全反射境界と港口境界とを区別するために用いた $N$ 行 $P$ 列の調整マトリックスであ り、 $\{\mathrm{C} 2\}$ は港口部における $\partial f_{2} / \partial n_{2}$ を表わす $P$ 次の列べクトルである。式(17)は港内境界上の $f_{2}\left(\vec{X}_{i 2}\right)$ が港口部 における $\partial f_{2} / \partial n_{2}$ の值によって表わされることを示している。しかし、\{C2\}は未知べクトルである。

\section{2 .2 港外境界上の散乱波関数}

港外境界上の $f_{3}\left(\vec{X}_{i 1}\right)$ について、境界を十分大きな数 $M$ (このうち左防波堤に相当する境界要素数を $N L B W$ 、 右防波堤のそれを $N R B W$ とする）に分割すると、式(13)を離散化して式(18)となる。

$$
(F 3)_{i}=-\frac{i}{2}\left[\sum_{j=1}^{M}\left(G 3_{n 1}\right)_{i j}(F 3)_{j}-\sum_{j=1}^{M}(G 3)_{i j}\left(F 3_{n 1}\right)_{j}\right], \quad(i=1,2, \cdots, M)
$$

ここで、式(18)中の各記号は次の通りである。

$$
\begin{aligned}
& (F 3)_{i}=f_{3}\left(\vec{X}_{i 1}\right), \quad(i=1,2, \cdots, M) \\
& \left(G 3_{n 1}\right)_{i j}=-k \cdot H_{1}^{(1)}\left(k r_{i j}\right) \frac{\partial r_{i j}}{\partial n_{1}} \Delta \partial 1_{j}, \quad(i, j=1,2, \cdots, M ; i \neq j)
\end{aligned}
$$




$$
\begin{aligned}
& \left(G 3_{n 1}\right)_{i i}=2 \int_{0}^{\frac{1}{2} \Delta \partial 1_{i}}\left(-k \cdot H_{1}^{(1)}(k r) \frac{\partial r}{\partial n_{1}}\right) d s, \quad(i=1,2, \cdots, M) \\
& (G 3)_{i j}=H_{0}^{(1)}\left(k r_{i j}\right) \Delta \partial 1_{j}, \quad(i, j=1,2, \cdots, M ; i \neq j) \\
& (G 3)_{i i}=2 \int_{0}^{\frac{1}{2} \Delta \partial 1_{i}} H_{0}^{(1)}(k r) d s, \quad(i=1,2, \cdots, M) \\
& \left(F 3_{n 1}\right)_{j}=\frac{\partial}{\partial n_{1}} f_{3}\left(\vec{X}_{j}\right), \quad(i=1,2, \cdots, M)
\end{aligned}
$$

式(18)をマトリックス表示して、まとめると式(20)となる。

$$
\{\mathrm{F} 3\}=\left([\mathrm{I}]+\frac{i}{2}[\mathrm{G} 3 \mathrm{n} 1)^{-1}\left(\frac{i}{2}[\mathrm{G} 3] \cdot[\mathrm{U} 3] \cdot\{\mathrm{C} 3\}\right)=[\mathrm{M} 3]\{\mathrm{C} 3\}\right.
$$

ここに、[U3]は港外の境界を海岸線部分とそれ以外の部分とに区別する $M$ 行 $(N L B W+P+N R B W)$ 列の 調整マトリックスであり、\{C 3$\}$ は防波堤と港口部における $\partial f_{3} / \partial n_{1}$ を表わす $(N L B W+P+N R B W)$ 次の列 ベクトルである。式(20)港外境界上の $f_{3}\left(\vec{X}_{i 1}\right)$ が防波堤と港口部における $\partial f_{3} / \partial n_{1}$ の値によって表わされるこ とを示している。しかし、\{C3\}の港口部に相当する部分べクトル\{C3P $\}$ は未知である。式(20)を部分マトリ ックス、部分ベクトルを用いて書き直すと次式となる。

$$
\left.\{\mathrm{F} 3\}=[\mathrm{M} 3]\{\mathrm{C} 3\}=\left[\begin{array}{ccc}
\mathrm{LCL} & \mathrm{LCP} & \mathrm{LCR} \\
\mathrm{LBL} & \mathrm{LBP} & \mathrm{LBR} \\
\mathrm{M} 3 \mathrm{PL} & \mathrm{M} 3 \mathrm{PP} & \mathrm{M} 3 \mathrm{PR} \\
\mathrm{RBL} & \mathrm{RBP} & \mathrm{RBR} \\
\mathrm{RCL} & \mathrm{RCP} & \mathrm{RCR}
\end{array}\right] \begin{array}{l}
\mathrm{C} 3 \mathrm{~L} \\
\mathrm{C} 3 \mathrm{P} \\
\mathrm{C} 3 \mathrm{R}
\end{array}\right\}
$$

ここに、部分マトリックスで表わした $[\mathrm{M} 3]$ の左列は左側の防波堤に相当し、文字の最後に $L$ 付けた。中 列は港口部に相当し、文字の最後に $P$ を付け、右列は右側の防波堤に相当し、文字の最後に $R$ を付けた。そ $し て 、 1$ 行目は左側の海岸線 $L C$ に相当し、2 行目は左側の防波堤 $L B 、 3$ 行目は港口部 $M 3 P 、 4$ 行目は右


左側の防波堤 $L に 、 2$ 行目は港口部 $P 、 3$ 行目は右側の防波堤 $R$ に相当する。

また、式(7)より、港外境界上における波高分布関数 $\{\mathrm{F} 1\}$ は次のようになる。

$$
\{\mathrm{F} 1\}=\{\mathrm{FI}\}+\{\mathrm{FR}\}+[\mathrm{M} 3]\{\mathrm{C} 3\}
$$

ここに、 $\{\mathrm{FI}\}=f_{i} 、\{\mathrm{FR}\}=f_{r}$ である。

2.2 .3 港内波高分布関数の計算

接続条件式(14)より\{C2\}を用いて港口部における\{C3P $\}$ を表現し、港内境界上の波高分布関数 $\{\mathrm{F} 2\}$ を計算 する。ここで、港口部では港外領域 1 と港内領域 2 の積分方向が反対になることを考虑して、マトリック ス[M3]の列について上下をひっくり返し、さらに行について左右をひっくり返したマトリックスを[M3]' と寸る。以後、マトリックス・ベクトルについて、その領域の積分方向と反対方向に配置されたものには プライムを付すことにする。

式(14)を変形し、ベクトル表現すると次式となる。

$$
\{\mathrm{C} 3 \mathrm{P}\}^{\prime}=-\left(\{\mathrm{DFI}\}_{\mathrm{P}}^{\prime}+\{\mathrm{DFR}\}_{\mathrm{P}}^{\prime}+\{\mathrm{C} 2\}\right)
$$

ここに、 $\{\mathrm{DFI}\}_{\mathrm{P}},\{\mathrm{DFR}\}_{\mathrm{P}}$ はをれぞれ港口の $\partial f_{i} / \partial n_{1}, \partial f_{r} / \partial n_{1}$ を表わす列ベクトルである。式(23)を式(22)に代 入すると式(24)となり、\{C2\}を用いて、港口部の波高分布関数 $\{\mathrm{F} 1\}_{\mathrm{P}}$ が次式にて表わされる。

$$
\{\mathrm{F} 1\}_{\mathrm{P}}^{\prime}=\{\mathrm{FI}\}_{\mathrm{P}}+\{\mathrm{FR}\}_{\mathrm{P}}+[\mathrm{M} 3 \mathrm{PR}]^{\prime}\{\mathrm{C} 3 \mathrm{R}\}^{\prime}-[\mathrm{M} 3 \mathrm{PP}]^{\prime}\left(\{\mathrm{DFI}\}_{\mathrm{P}}^{\prime}+\{\mathrm{DFR}\}_{\mathrm{P}}^{\prime}+\{\mathrm{C} 2\}\right)+[\mathrm{M} 3 \mathrm{PL}]^{\prime}\{\mathrm{C} 3 \mathrm{~L}\}^{\prime} \quad \text { (24) }
$$

ここに、\{F1 $\}_{\mathrm{P}}$ は、港外境界上の波高分布関数 $\{\mathrm{F} 1\}$ のうち港口部に相当する部分ベクトルであり、 $\{\mathrm{FI}\}_{\mathrm{P}} 、$ $\{\mathrm{FR}\}_{\mathrm{P}}$ はそれぞれ港口の $f_{i}, f_{r}$ を表わす列べクトルである。[M3PR]は [M3]の右側の防波堤境界に相当する $P$ 行 $N R B W$ 列マトリックスであり、 $[\mathrm{M} 3 \mathrm{PP}]$ は $[\mathrm{M} 3]$ の港口部に相当する $P$ 行 $P$ 列マトリックス、 $[\mathrm{M} 3 \mathrm{PL}]$ は $[\mathrm{M} 3]$ の左側の防波堤境界に相当する $P$ 行 $N L B W$ 列マトリックスである。\{C $3 \mathrm{R}\}$ は右側の防波堤境界境界 
上の $\partial f_{3} / \partial n_{1}$ を表わ寸 $N R B W$ 次の列べクトル、 $\{\mathrm{C} 3 \mathrm{~L}\}$ は左側の防波堤境界上の $\partial f_{3} / \partial n_{1}$ を表わす $N L B W$ 次の 列ベクトルであり、この 2 つ列ベクトルは既知である。

一方、港口部の波高分布関数 $\{\mathrm{F} 2\}_{\mathrm{P}}$ は次式で表わされる。

$$
\{\mathrm{F} 2\}_{\mathrm{P}}=[\mathrm{M} 2 \mathrm{P}]\{\mathrm{C} 2\}
$$

ここに、 $[\mathrm{M} 2 \mathrm{P}]$ は $[\mathrm{M} 2]$ の港口部に相当する $P$ 行 $P$ 列マトリックスである。

そこで、港口部について、式(24) と式(25) とから接続条件 $\{\mathrm{F} 1\}_{\mathrm{P}}^{\prime}=\{\mathrm{F} 2\}_{\mathrm{P}}$ を適用すれば未知ベクトル $\{\mathrm{C} 2\}(=$ $\left.\partial f_{2} / \partial n_{2}\right)$ に関寸るP元連立 1 次方程式(26)力得られる。

$$
\left([\mathrm{M} 2 \mathrm{P}]+[\mathrm{M} 3 \mathrm{PP}]^{\prime}\right)\{\mathrm{C} 2\}=\{\mathrm{FI}\}_{\mathrm{P}}+\{\mathrm{FR}\}_{\mathrm{P}}+[\mathrm{M} 3 \mathrm{PL}]^{\prime}\{\mathrm{C} 3 \mathrm{~L}\}^{\prime}-[\mathrm{M} 3 \mathrm{PP}]^{\prime}\left(\{\mathrm{DFI}\}_{\mathrm{P}}^{\prime}+\{\mathrm{DFR}\}_{\mathrm{P}}^{\prime}\right)+[\mathrm{M} 3 \mathrm{PR}]^{\prime}\{\mathrm{C} 3 \mathrm{R}\}^{\prime}
$$

式(26)を解くことにより港口部における未知べクトル $\{\mathrm{C} 2\}$ が定まる。これを式(17)に代入すれば、港内境界上 における波高分布関数 $\{\mathrm{F} 2\}$ が求められる。さらに、式(5)より港内任意点の波高分布関数 $f_{2}$ が計算できる。

\section{2 .4 港外波高分布関数の計算}

式(26)を解くことにより得られた $\mathrm{C} 2\}$ を式(23)に代入すれば港口部における\{C3P\}が定まる。これと式(21)に より港外境界上における波高分布関数 $\{\mathrm{F} 3\}$ が求められる。さらに、式(12) と式(7)より港外任意点の波高分布 関数 $f_{1}$ 計算できる。

以上が数值計算の計算モデルである。

\section{3. 数值計算}

\section{1 計算手法の検証}

3.1 .1 既往の研究との比較

図 5 は、松岡 ${ }^{(7)}$ が有限要素法により計算した振幅增 幅率の分布である。このときの計算条件は、水深= $5.0 \mathrm{~m}$ 、波向き $=110 \mathrm{deg}$ 、反射率 $=1.0$ 、周期 $=384 \mathrm{~s} \tau$ ある。この分布図と開発した計算手法による結果と を比較する。ここで、図 5 の港湾は港口を 2 つ有し

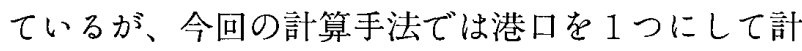
算手法を適用した。そのため両者は完全に同じでは ない。

この港湾に対して、同じ計算条件で計算した結果 が図 6 である。この場合、海岸線の積分範囲は散乱 波の減衰項が $1 / 10$ に減衰する距離までとした。これ より、港外の左側全域と右側の海岸線付近の分布形 状はよく一致していることがわかる。しかし、港外 の右側防波堤付近は開口部がないため異なった分布 となっている。また、港内の振幅增幅率の分布も図

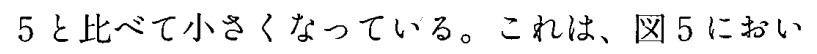
ては、港内から見て手前に 2 つ目の港口があること により、この港口が振動の節となる副振動現象が引 き起こされ、增幅率が大きくなっているためと考兄 られる。

\subsection{2 境界内部点が境界に近づいたときの計算 波高}

港外および港内の完全反射境界における境界条件 の検証を行うため、境界内部点が境界に近づいたと きの波高を計算した。図 7 に示寸港内外の10箇所の

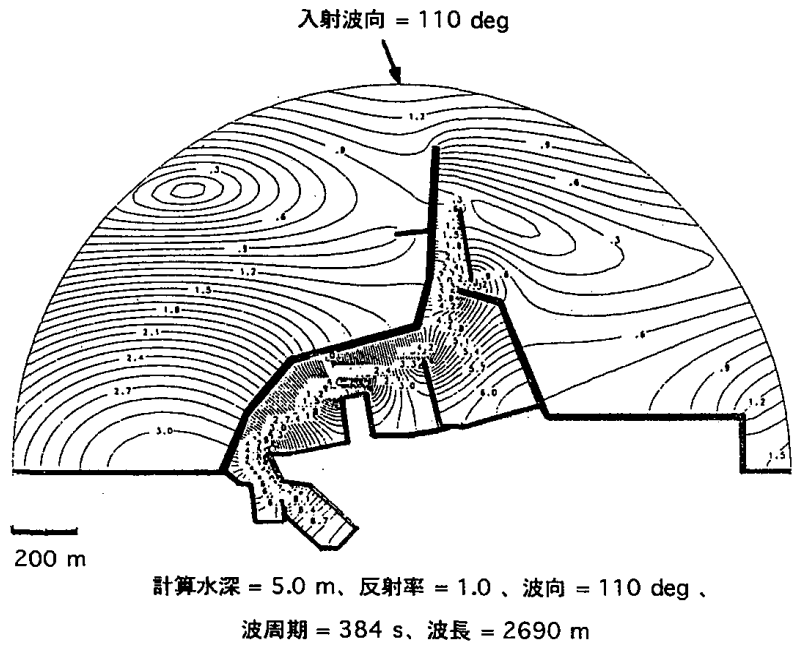

図 5 松岡(7)が有限要素法により計算した振幅增幅率の分布

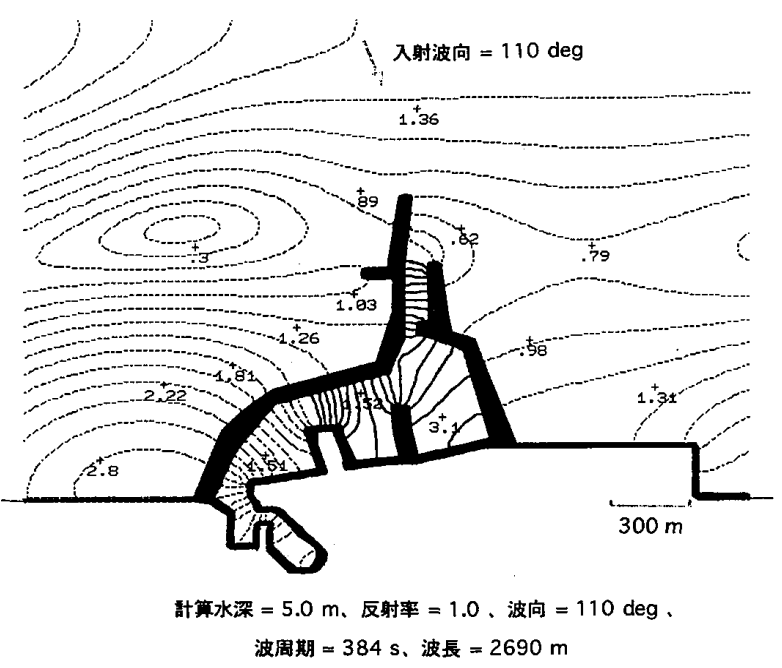

図 6 開発した手法により計算した振幅堌幅率の分布 


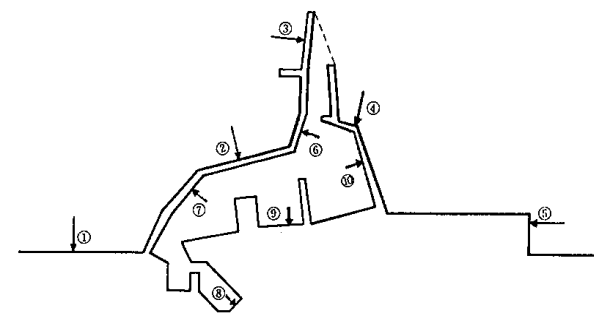

図 7 境界条件の検証のための計算点

ポイントにおいて、境界に対して直角に 近づいたとき、境界内部点としての計算 波高 $H$ の境界上の計算波高 $H b$ に対する比 を求めたのが図 8 である。ここに、図 8 のポイント 1 〜の図は港外任意点が、 周期384秒の波の波長の $1 / 10$ の距離から境 界に直角に近づいたときの比を示すものであり、ポ イント 6〜10の図は港内任意点か境界から20m離れた 地点から境界に近づいたときの比を示している。こ れより、港内および港外の完全反射境界における境 界条件 $\partial f_{1} / \partial n_{1}=0, \partial f_{2} / \partial n_{2}=0$ を満足していることが わかる。

\section{1 .3 散乱波の分布}

散乱波関数はその定義から港の存在に負う反射波 についての修正波高分布関数である。そこで散乱波 の分布を図 9 に示す。このときの海岸線の積分範囲 は散乱波の減衰項が $1 / 10$ に減衰する距離である。こ こで、海岸線の積分範囲を散乱波の減衰項が $1 / 24$ に 減衰する距離までとした場合の散乱波の分布が図10 である。闵 9 と図10より、港から離れたところで差 が顕著となっており、港の周辺では大きな差はない ことがわかる。さらに、このときの港の周辺の振幅 増幅率の分布を示したものが図11である。四 6 と図 11より、分布形状にほとんど差はなく、増幅率もほ ぼ等しいことがわかるこれらにより港湾周辺の増 幅率の分布について、海岸線の積分範囲は散乱波の 減衰項が $1 / 10 に$ 減衰する距離として近似できること がわかる。

\section{2 周辺形状を考虑した副振動の数値計算}

港湾の形状を分類する場合、内陸に掘込んで発展 していく掘込み型と海に向かって発展していく埋め 立て型に分けることができる(16)。そこで、港内形状 が同一の掘込み型港湾と埋め立て型港湾（図12）を 考える。さらに、これまでのLeeによる計算手法が適 用できる防波堤のない掘込み型港湾（図12）を考え、 これらの港湾に対して副振動の計算を行う。

それぞれの港湾に対する振幅増幅率の周期特性を示したものが図12である。ここで、計算点は図中×印 の位置とし、計算に用いた条件は水深が $5.0 \mathrm{~m}$ 、入射波向は90degである。これより、3つの場合で増幅率 のピークをとる周期がほぼ同じであることがわかる。また、図12において増幅率が最大となるそれぞれの

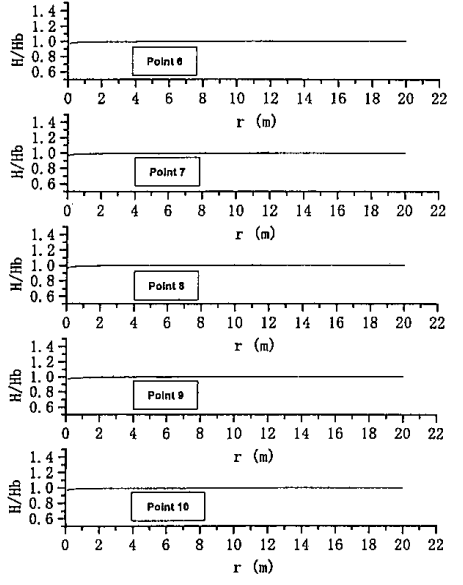

図 8 境界内の任意点が境界に近づいたときの $\partial f_{1} / \partial n_{1}=0 、 \partial f_{2} / \partial n_{2}=0$ 確認

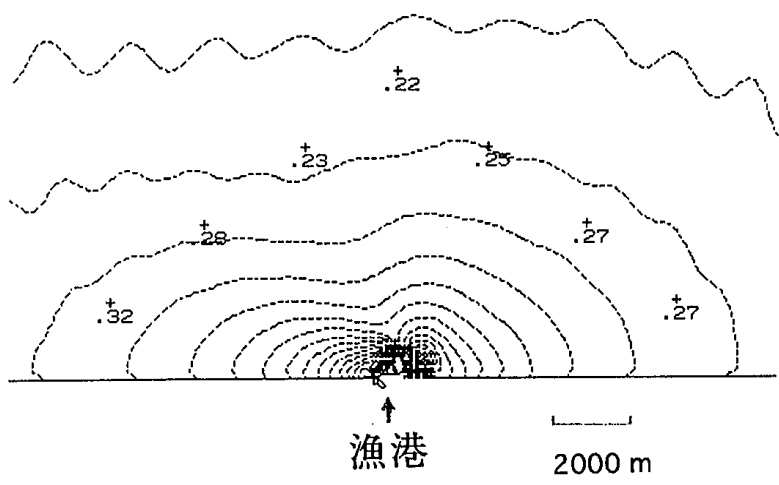

計算水深 $=5.0 \mathrm{~m}$ 、反射率 $=1.0$ 、波向 $=110 \mathrm{deg}$ 、 波周期 $=384 \mathrm{~s}$ 、波長 $=2690 \mathrm{~m}$

図 9 散乱波の分布（散乱波の減衰項が $1 / 10$ まで 減衰する距離を積分範囲とした場合）

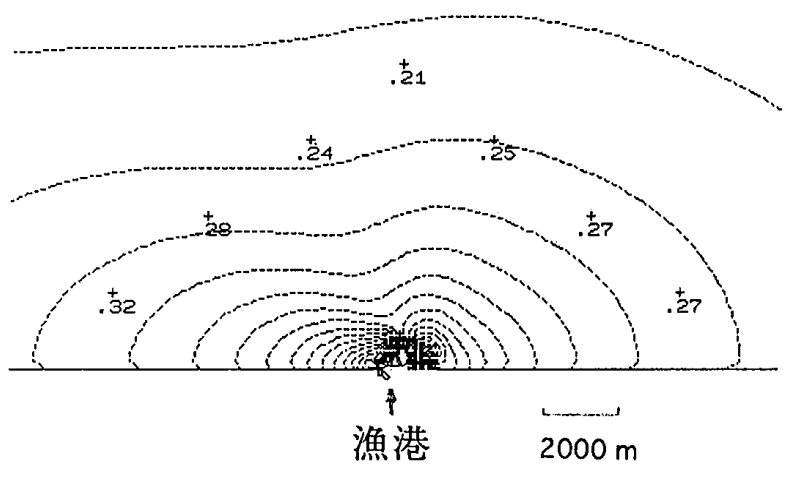

計算水深 $=5.0 \mathrm{~m}$ 、反射率 $=1.0$ 、波向 $=110 \mathrm{deg}$ 、

波周期 $=384 \mathrm{~s}$ 、波長 $=2690 \mathrm{~m}$

図10 散乱波の分布（散乱波の減衰項が1/24まで 減衰する距離を積分範囲とした場合) 




図11 振幅増幅率の分布（散乱波の減衰項が1/24 まで減衰する距離を積分範囲とした場合)

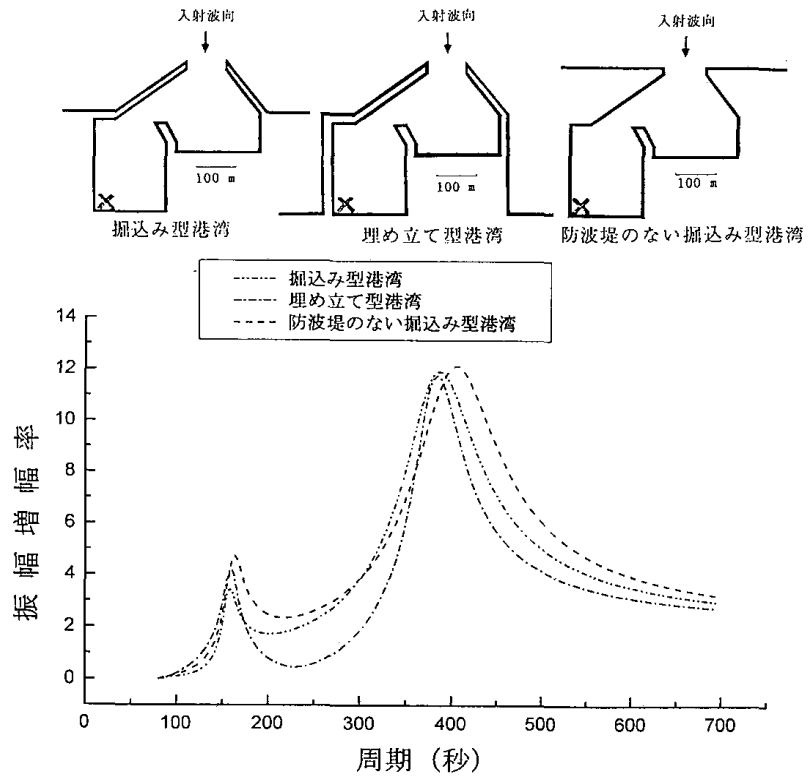

図12＼cjkstart振幅増幅率の周期特性



困13a 掘込み型港湾の振幅増幅 率の分布（周期388秒）

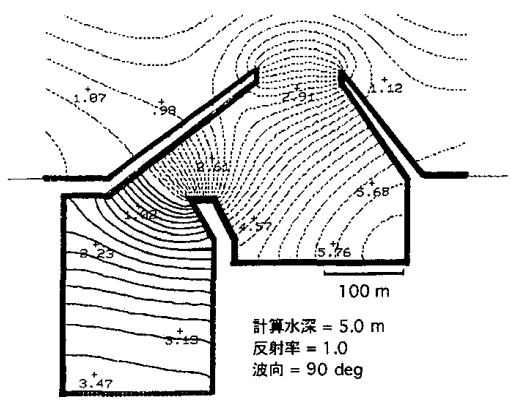

図13b＼cjkstart掘込み型港湾の振幅増幅 率の分布 (周期159秒)

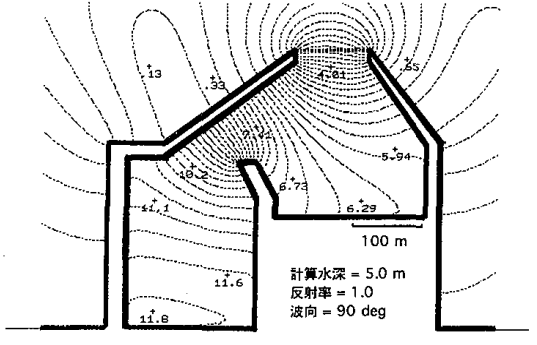

図 $14 \mathrm{a}$ 埋め立て型港湾の振幅増 幅率の分布（周期385秒）

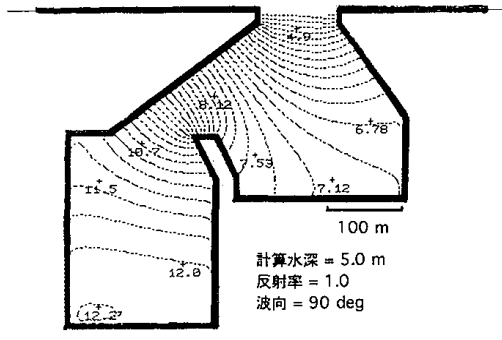

図15a＼cjkstart防波堤のない掘込及型港湾の振 幅増幅率の分布 (周期406秒)

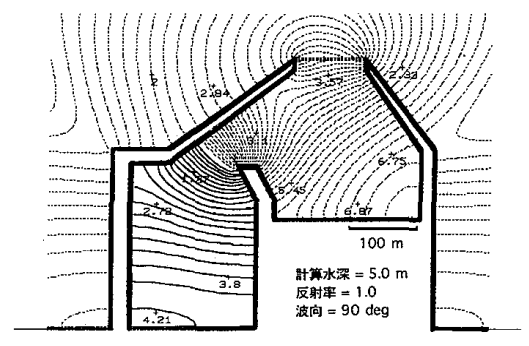

図14b 埋め立て型港湾の振幅増 幅率の分布（周期160秒）

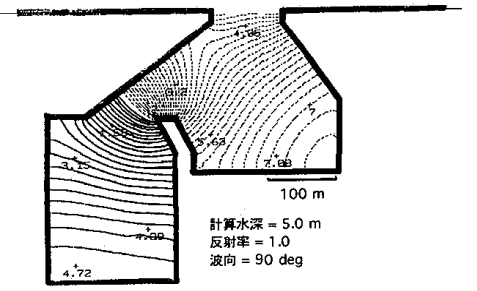

四15b＼cjkstart防波堤のない掘込み型港湾の振 幅増幅率の分布(周期165秒)

周期について、振幅增幅率の分布を示すと、掘込み型港湾に対するそれが図 $13 \mathrm{a} 、 \mathrm{~b} 、$ 埋め立て型港湾が 図14a、b、海岸線が一直線で防波堤のない掘込み型港湾が図15a、bである。第 1 モードの振動が引き起こ されている図13a、図14a、図15aでは、増幅率は防波堤のない掘込み型港湾が最も大きい。しかし、港内の 分布形状は類似している。また、図13b、図14b、図15bでは、港内中央部の防波堤付近が振動の節となる第 2 モ一ドの湾水振動が引き起こされて扔り、港内の分布形状は類似していることかわかる。しかし、港外 の分布形状は図13b と図14bとで異なっている。 


\section{4. おわりに}

本報告においては、港外の周辺形状を考慮できる副振動の数値計算手法を開発し、既往研究との比較検 討から手法の妥当性を検証した。また、一般的な形状の 3 つの港湾に対してこの手法を適用した。

本報告により得られた主な結果をまとめると以下の通りである。

（1）開発した数值計算手法により、港内だけでなく港外についても任意形状の港湾に対して副振動現象の 解析が可能である。

(2) 海岸線の積分範囲は散乱波の減衰項が1/10に減衰する距離として近似できることを確認した。

（3）掘込み型港湾と埋立て型港湾とでは副振動の共振周期が近く、港内の増幅率分布は似ている。

（4）掘込み型港湾と埋め立て型港湾とでは港外の増幅率分布が異なり、周辺での波高分布が定量的にわか るようになった。

な招、本モデルに和いては、水深が变化する場合、海岸線が一直線でない場合、港口が複数存在する場 合などの考慮を行っていない。今後はこれらの影響に関する検討も必要である。

\section{参 考 文 献}

（1）白石 悟・久保雅義・上田 茂・榊原繁樹：倸留システムに着目した長周期波に対する船舶の動摇抑 制対策，海岸工学論文集，第42巻，pp.941-945，1995.

（2）喜岡 涉・柏原謙爾・岩垣雄一：不規則波群に伴う 2 次長周期波の湾水振動，土木学会論文集N No.473/ $\ulcorner$ II -24 , pp.55-64, 1993.8 .

（3）合田良実：浅海域における波浪の砕波変形，港湾技術研究所報告，第14巻第 3 号, pp.59-106, 1975.9 .

(4) Munk, W.H. : Surf beats, Trans.A.G.U., Vol.30, No.6, pp.849-854, 1970.

（5）久保雅義・榊原繁樹：荷役稼働率計算における波群・副振動による長周期波の影響について, 海岸工 学論文集, 第42巻, pp.931-935, 1995.

（6）合田良実：長方形および扇形の港の副振動について, 第10回海岸工学講演会講演集, pp.53-58, 1963.

（7）松岡道男：中小港湾の港内埋没におよぼす長周期波の影響に関する研究，大阪大学学位論文，1994.

(8) Chen, H.S. and C.C.Mei : Oscillations and wave forces in an offshore harbor, Ralph M.Parsons Lab.,Report No.190, M.I.T,1974.

（9）坂井藤一・月岡康一：波動解析への有限要素法の適用 (第 2 報), 第21回海岸工学講演会論文集, pp.45 $-48,1974$.

(10) Lee, Jinn-Jen : Wave induced oscillation in harbors of arbitrary shape, Calif. of Tech., 1970.

(11) 椹木 亨・久保雅義：Slip 内の波高分布に関する二, 三の考察, 日本航海学会論文集, 第 63 号, pp.97 $-106,1980$.

(12) 浜中建一郎：グリーンの公式を用いた静稳度解析における種々の境界条件について, 海岸工学論文集, 第42巻, pp.996-1000, 1995.

（13）日下 理・辰本正弘・岩崎 晃: 任意反射率境界々水深変化を考慮した港内波高分布の解析, 第30回 海岸工学講演会論文集, pp.128-132, 1983.

(14) 久保雅義・斎藤勝彦・椒原繁樹：斜面前面における係留船の船体運動について，日本航海学会論文集， 第78号, pp.73-81, 1988.

(15) 寺澤寛一：数学概論, 岩波書店, pp.486-490, 1954.

(16) 長尾義三: 港湾工学, 共立出版, pp.181-182.

\section{質 疑 応 答}

榊原繁樹（横浜ゴム侏)：散乱波の減衰項は何項まで取っていますか。

前田保男：船体運動や浮体構造物の運動、あるいは地震動のように水面との境界が運動する場合には、動 く境界の速度ポテンシャルを考慮して式(4)に無限級数項を加える必要があります。しかし、本報告にお いては、海岸線、防波堤、構内境界といった静止境界のみで囲まれた水面状態の議論であり、無限級数 第 1 項のみで充分です。 